\title{
Implementation of Voice Recording Activities in Improving Mandarin Oral Fluency
}

\author{
Suo YanJu \\ Department of Major language studies, Islamic Science University of Malaysia (USIM) \\ Suo Yan Mei \\ Department of modern language, Sultan Idris Education University, Malaysia (UPSI)
}

Yuslina Mohamed

Department of Major language studies, Islamic Science University of Malaysia (USIM)

\begin{abstract}
The purpose of this study was to investigate the effectiveness of voice recording activities in improve undergraduate language students' oral fluency in Mandarin as a foreign language. The data collected for this study from 44 year two undergraduate Level three Mandarin learners in semester 1 2016/2017 participated Online questionnaire, and data collected and analyzed according to the attitudes and effectiveness of using voice recording activities in the classroom. The study find out that voice recording activities are effective to help foreign language learners to improve oral fluency. Mandarin language teachers might consider devoting additional attention to Mandarin oral fluency teaching by using new technology like voice recording, whatApp, Wechat ect.to help Mandarin learners to improve their Mandarin oral fluency especially for learners who are shy and lack of confidence. It will help learners to improve their foreign language leaning in general.
\end{abstract}

Keywords: Mandarin oral fluency, foreign language learning, voice recording

\section{Introduction}

Mandarin course has been offered by many universities in the world. It has been offered in Islamic Science University of Malaysia since 2007, there are there levels: Mandarin I, Mandarin II and Mandarin III. It is compulsory subject for faculty of Major language studies undergraduate students. Majority of students are Malay students. Students need to complete all there levels before they graduate. Students have been taught by part time instructors since the subject has been offered till 2016. There are total fourteen weeks, three hours per class. There forty two hours for each level. Students who are taking Mandarin three have already completed Mandarin I and Mandarin II in their previous semesters, however as a new lecture in faulty major language studies, I have been observed students in Mandarin III are not able to speak even simple sentences in Mandarin, some of them even cannot pronounce some of Pinyin which they should be able to master it at their Mandarin I. Another issue I have faced is a lack of opportunities for students to speak Mandarin outside the classroom. In the Mandarin as a foreign language (MFL) setting, generally, the only chance for students speaking Mandarin occurs in the classroom. Learners are very shy and passive in the class activities at beginning of semester. One of research has been done by Siti Maziha \& Nik Suryani Melor Md (2010) the factors discourage Malay students participate in classroom activities are:

(1) Negative classmate traits ways such as creating disturbances, testing, not being cooperative or patient.

(2) Negative lecture trains ways such as lectures' poor teaching skills, being impatient and unapproachable.

(3) Negative students' traits such as afraid to speak in the foreign language, afraid to make mistakes and did not want to feel embarrassed in front of class.

Those factors discourage students from participating in class activities. As foreign language learners the main objective of learning foreign language is to be able to communicate with the target language. One of the ways to help learners to improve their oral fluency is to speak the target language inside and outside of classroom. Another study has been done 
by Pandianet al. (2011) who stressed that students' inability to speak as fluently as they can is often reflected as unwillingness and lack of confidence when it comes to speaking. Most of the students often need to be encouraged by their lecturers to participate in speaking activities. Students should realize that when they are in the university; they must be physically and mentally prepared to face all challenges.

This study aims to investigate the effectiveness of voice recording activities in improve undergraduate language students' oral fluency in foreign language classrooms.

\section{Literature Review}

\subsection{Voice recording activities}

Technology use in the foreign language classroom is not new now, it has been moving from audiotapes to $C D$. Unwieldy cassette players and poor-quality microphones are a thing of the past. Now, modern technology in the form of digital audio recording offers unprecedented ease in student-produced voice recordings in classroom settings. Digital audio recording is a useful tool in foreign language classrooms where a primary goal is for students to practice speaking the target language, hear how they sound, and improve their speaking proficiency. This kind of self-monitoring is an important part of language production for all levels of foreign language learners.

Nowadays Free, easy-to-use smartphone application such as voice recorder is tool that facilitates and document student practice speaking the target language. By recording themselves speaking with the application, students' original language production is recorded and students have the opportunity to go back and hear their own speaking before they send it to their language instructors. Students are able to reflect on their accent, grammar, fluency, intonation, etc. The power of audio recordings is that the student can build up a whole collection of recordings that show their development over a period of time. These can easily be shared with their peers and instructors. Voice recording App is to be one of the easiest tools that language learners used for making simple audio recordings. Learners just need to click one button, record their voice and then choose from a variety of ways of saving the recording including as a downloadable MP3 file. They can send their audio file to their class whatsApp group for their language instructors and their peers to view and get feedback.

\subsection{Voice recording activities in improving students' oral fluency}

Study has been done by Pop, Tomuletiu, \& David voice recording tools have been introduced and used in a variety of ways in language instruction in an attempt to provide learners with opportunities to produce oral output "as they allow language students to practice and enhance their speaking skills outside the classroom while receiving feedback on their performance" (2011, p. 119). With easy-to-use voice recording available on smart phones, learners can capture their speaking for selfassessment. The development of mobile and tablet applications are offering numerous ways for students to explore their own voice by recording themselves speaking. The teachers can then listen and provide feedback on their oral performance or get students to review or even self-review their work.

\subsection{Statement of the Problem}

Malay undergraduate students in Mandarin III are not able to speak the target language although they have completed the Mandarin I and Mandarin II; some of them even cannot pronounce Pinyin properly which they should master it in Mandarin I. There are no full time instructors to teaching this subject since the subject has been offered in 2007 till 2016. The part time instructors are not well-trained to teach this subject. Students are lack opportunities to speak the target language that often and they have no confidence to speak in the target language since they are afraid to make mistakes.

To study foreign language, learners should be able to read, write, comprehend and speak. These are four skills are emphasized by all of the language learners. The speaking skills are the most of important skills, because to be able to communicate is the main objective of foreign language learning. See \&Ching (2013) in their study mentioned that more attention should be paid on the audio-oral skills because the main reason an individual learns a foreign language is to communicate in the language especially orally. However, study find out those students experienced the most stress when having to give face-to-face oral presentations with the instructor. (Woodrow, 2006) Research hopes that through this study to find out the perception of students towards the oral recording activities and effectiveness of these activities in improving learners' oral fluency. The study hopes to answer the following research questions:

1. What is learner's attitude towards voice recording activities in foreign language classroom? 
2. How effective of voice recording activities in learners' oral fluency?

\subsection{Classroom participation}

Classroom participation is very important because students' learning taking place through classroom participation (L.S. Vygotsky, 1978) according to L.S Vygotsky students' learning through social interaction and cultural. Therefore, classroom as social context which students interact each other through the classroom activates. L.S. Vygotsky's theory emphasized that teacher-student and students-students interaction becomes medium of sharing knowledge and communication. Thought interaction students are communicating each other. However, through observation the researcher realizes that majority of Malaysian university students are not eager to participate in the class activities, they are not willing to speaking in front of peers. The factors of discourage Malaysia undergraduate students from participate in the classroom in the foreign language There are few studies found that the factors of discourage Malay undergraduate students to participate in class activities. Voice recorder has been required in BMA3033 class. Students are using voice recorder in their free time to record the topics have been given by their instructor. Its help students and motivate foreign language learners to practice their listening and speaking skills more often after class.

\section{5 purpose of this study}

The main purpose of the current study aims to assess the extent of voice recording activities to improve Malay undergraduate students' oral fluency in Mandarin language based on the module provided. It also helps lecturers to choose suitable strategies and approach in teaching Mandarin language. Besides that, this study also helps the lecturer to build up self confidence among students in speaking foreign language inside and outside classroom.

\section{Research Methodology}

\subsection{Participants}

The data used in in this study collected by 60 university undergraduate students who were enrolled in Mandarin level three classes during semester one academic year 2016/2017. All of them are year two major in Arabic and communication nonnative mandarin speaker. Those students have completed Mandarin level one and level two in their previous semesters. Two instruments were used in this study. One was a student online survey questionnaire and other on is based on classroom observation.

\subsection{Data collection}

This research has conducted in semester one 2016/2017 academic year. The research used a set of online questionnaire which set in Google form send it to the participants at the end of semester. The objective of survey has been informed students before they complete the questionnaire. There were 44 students out of 60 responded online questionnaires. The questionnaire is divided into two parts. First part includes items to gather information about learner's attitude towards voice recording activities in Mandarin classroom. The part two includes items to gather information of the research objectives. The participants of this research were students who took Level 3 Mandarin as a foreign language course in Islamic Science university of Malaysia Nilai campus. The sample of this research consists of respondents. After all of the questionnaires were returned, the researcher first checked the number of completed questionnaires to determine the number of respondents involved in this research.

\section{Data Analysis and Results}

Quantitative data from student survey were analyzed via the online survey tool "Google form".

The data collected by Google Form were analysis.

\subsection{Learners' attitude towards voice recording activists in Mandarin language learning.}

\section{Table}

Table 1.Participants' attitude towards using the voice recording actives in Mandarin learning

\begin{tabular}{|l|l|l|l|l|l|}
\hline & Always & Usually & Sometimes & Rarely & Never \\
\hline I redo the voice recording entries when the speech does not & $45.5 \%$ & $25 \%$ & $15.9 \%$ & $3 \%$ & $3 \%$ \\
\hline
\end{tabular}




\begin{tabular}{|c|c|c|c|c|c|}
\hline flow well. & & & & & \\
\hline $\begin{array}{l}\text { I redo the voice recording entries when the intonation does } \\
\text { not sound right. }\end{array}$ & $38.6 \%$ & $27.3 \%$ & $18.2 \%$ & $9.1 \%$ & $6.8 \%$ \\
\hline $\begin{array}{l}\text { I redo the voice recording entries when there are } \\
\text { grammatical mistakes on it. }\end{array}$ & $31.8 \%$ & $45.5 \%$ & $13.6 \%$ & $2.3 \%$ & $6.8 \%$ \\
\hline $\begin{array}{l}\text { I redo the voice recording entries when the word choice is } \\
\text { not quite right. }\end{array}$ & $29.5 \%$ & $36.4 \%$ & $18.2 \%$ & $9.1 \%$ & $6.8 \%$ \\
\hline $\begin{array}{l}\text { I redo the voice recording entries when the pronunciation } \\
\text { does not sound right }\end{array}$ & $27.3 \%$ & $45.5 \%$ & $15.9 \%$ & $4.5 \%$ & $6.8 \%$ \\
\hline $\begin{array}{l}\text { I redo the voice recording entries when the organization of } \\
\text { ideas is not right. }\end{array}$ & $29.5 \%$ & $36.4 \%$ & $18.2 \%$ & $9.1 \%$ & $6.8 \%$ \\
\hline I practice my mandarin voice recording on regular basis. & $38.6 \%$ & $29.5 \%$ & $27.3 \%$ & $2.3 \%$ & $2.3 \%$ \\
\hline $\begin{array}{l}\text { I always listen to the voice recording sent by my } \\
\text { classmates. }\end{array}$ & $22.7 \%$ & $27.3 \%$ & $40.9 \%$ & $9.1 \%$ & 0 \\
\hline $\begin{array}{l}\text { I always listen to others 'recording to improve my own } \\
\text { recording }\end{array}$ & $34.1 \%$ & $34.1 \%$ & $20.5 \%$ & $4.5 \%$ & $6.8 \%$ \\
\hline
\end{tabular}

From the table above we can conclude that the attitude of using voice recording in improve learners' Mandarin oral fluency is quiet positive. Learners practiced before they send their final work to their group WhatsApp group. After their first attempt learners normally will listen to their work first, once they realize there are some errors they will redo their voice recording. Sometimes they will listen to their peers' work that has sent early in order to improve their own work. From the data collected the research found out that $92.2 \%$ of learners would like to listen to their peers work in order to improve their own work. Learner will redo their voice recording when the pronunciation and intonation does not sound right, or speech does not flow well, or there are some grammatical errors. There are less than $10 \%$ of learners will not redo their work.

After one semester I have been observing my Mandarin three students from both classroom, I have found that learners' Mandarin speaking have been improving from not be able to produce simple sentence to able to introduce themselves in complex sentences with minor errors in their presentation. The attitudes of Learners' participation are also positive: majority of learners are willing to participant in class activities and eager to speak out in class who are very shy at beginning of semester.

\subsection{Effectiveness of using voice recording in learning Mandarin language by Malay foreign language learners.}

\subsubsection{Improve listening skills}

Majority of students have trouble understanding every spoken Mandarin word when they first listen to the conversation or presentation which their peers have posted in their WhatsApp group. Later they can listen to it again and hear any of the words they might have missed the first time. These recordings will also help students become familiar with the sound of their classmates while they speak.

The results from participants' survey indicate that $62.5 \%$ of the students agreed and $25 \%$ strongly agreed that the Voice Recorder activities helped their listening skills. Students' statements indicate that the reason for this is mainly because students could listen to others' recorded for each time again and again until they could understand it and get some idea for their own work. Another reason has been given that the language instructors' feedback provides the learners opportunities to improve their listening skills. Thus the tool offered the students more listening opportunities.

\subsubsection{Improve pronunciation}

Improving learners' pronunciation is an important goal when learning Mandarin, due to unique of tone language of Mandarin, good pronunciation is even more important because will cause misunderstanding between speaker and receivers if your do not pronounce correctly. Voice recorder is a useful tool to help learners to improve their pronunciation.

From data collected is this study, researcher found out that $36.4 \%$ of participants strongly agree and $54.5 \%$ of participants agree that this voice recording activity help them improved their Mandarin pronunciation. The reasons have been given that learners record their own speaking on regular basis, and then they can listen back to the recording. Listening back the aim is to find incorrect tones and other repeated mistakes. After listening back they pick up the wrong pronunciations and 
correct it then re-record the work that correcting the mistakes or problems that they found earlier. Learners are trying to do this on regular basis with a new passage of text and to make sure their Mandarin pronunciations are getting better form time to time.

\subsubsection{Improve grammar}

From the data collected there are $31.8 \%$ of participants strong agree and $59.1 \%$ of participants agree that this voice recording activities helped them to improve their Mandarin grammar accuracy. There are less than $10 \%(9.1 \%)$ of participants disagree that the activity helped with their grammar accuracy. In terms of grammatical accuracy in oral output, learners generally performed better after Self-reflection. This have been approved by many researchers (Cooke, 2013; Huang, 2008; Lynch, 2007; Stillwell et al., 2009)

\subsubsection{Help learners with their speaking skills}

When learners speak Chinese they are not aware of their own pronunciation, tone and voice. Recording their own voice and listen it back can help them to be aware of their own mistakes. They can record as many times as they want and try to compare the files will reveal their strength and weaknesses. This reflection will help learners in improving their oral fluency. Data from this study find out that $97 \%$ of participants indicated that voice recording activities help them a lot in their Mandarin speaking skills, only 3\% of participants indicated that this activity help them a little in their Mandarin speaking skills. One of participant wrote that "using voice recording to record what I want to say and then can listen to my own voice. I used to force myself to listen to the sound bites until I understood every word and then I would reply myself. This was much more like a real conversation, but being able to listen as many times as I wanted. I believe that using voice recording is a great way to increase our confidence in improving our Mandarin speaking skills, exercising our ability to communicate in Mandarin using real-life conversation".

\subsubsection{Help leaners with their self-reflection and confidence}

Mennim (2003) suggested that rehearsed oral output and revisions of their recording after self-reflection would promote more sophisticated and complex use of vocabulary and language form. Students notice their use of simple vocabulary in their recordings. Increase in complexity after recording, self-assessing and revising students' oral output. Learners do a lot of practices record their own voice before they are satisfied with their final pieces of the work. Each time they record and listen it back they might find their weakness and try to improve it. The more times they record their own work, the better they are getting. After they sent their final work to their whatApp group, they received the comment and feedback from their peers and language instructions. This gives them more confidence and courage to speak more in target language. One of participant mentioned in the survey "it gives me confidence to speak Chinese fluently" another participant also indicate that "it rise my confidence in speaking the language more often and I am not afraid now to make mistakes."

\section{Conclusion and Suggestios}

The study investigated the voice recording activities in Mandarin language in improving leaner's oral fluency. The integration of voice recording of learners' own practices outside classroom could be useful for promoting students' oral output outside the classroom as well as awareness of their performance and strengthening their sense of ownership over their own learning.

Voice recording activities give a lot of benefits to improve Mandarin oral fluency among Malay undergraduate students. The findings of the study indicate that students' interest in learning Mandarin speaking skills is influenced by this activity. The voice recording allows the students to practice speaking Mandarin language fluently with the guidance from the lecturer. Besides that, voice recording activities were fun, motivating, and useful to help avoiding the gap between active students and passive students, helpful to build self-esteem and confidence among students. The learning process also becomes more student-centered rather than a teacher-centered. Therefore it is important to create an environment that will support the students' learning process and offer opportunities for acquiring Mandarin speaking skills as well as other basic skills in Mandarin language. Pop, Tomuletiu, \& David mentioned that attempt to provide learners with opportunities to produce oral output "as they allow language students to practice and enhance their speaking skills outside the classroom while receiving feedback on their performance" (2011, p. 1199). There is no doubt that more research is needed to investigate the audiobased activities in improving foreign language learners' oral performance. 


\section{References}

[1] Cooke,S.D.(2013).Examining Transcription, Autonomy and Reflective Practice in Language Development. RELC Journal, 44(1), 75-85.

[2] Fassinger, P. A. (2000). How classes influence students' participation in college classrooms. Journal of Classroom Interaction, 35, 38-47.

[3] Fassinger, P.A. (1995). Professors' and students' perceptions of why students participate in class. Teaching Sociology. 24, 25-33.

[4] Gomez, A.M., Arai, M.J., \& Lowe, H. (1995). When Does a Student Participate in Class ? Ethnicity and Classroom Participation. Paper presented at the Annual Meeting of the Speech Communication Association (81st, San Antonio, TX).

[5] Huang, S. C. (2008). Raising Learner-Initiated Attention to the Formal Aspects of Their Oral

[6] Production through Transcription and Stimulated Reflection. IRAL-International Review of

[7] Applied Linguistics in Language Teaching, 46(4), 375-392.

[8] Lynch, T. (2001). Seeing what they meant: Transcribing as a route to noticing. ELT

[9] Journal, 55(2), 124-132.

[10] Pandian, A., Tan, S. S. B \& Sheikh Abdul Malik. (2011). Teaching and learning language: Current trends andpractices. Universiti Sains Malaysia: Pulau Pinang.

[11] Pop, A., Tomuletiu, E. A., \& David, D. (2011). EFL speaking communication with asynchronous voice tools for adult students. Procedia-Social and Behavioral Sciences, 15, 1199-1203.

[12] Siti Maziha Mustaphaa, Nik Suryani Nik Abd Rahmanb, Melor Md.Yunusc (2010) Factors influencing classroom participation: a case study of Malaysian undergraduate students .Procedia Social and Behavioral Sciences 9.1079-1084.

[13] See.S. Y \&Ching.T.H (2013) Mandarin as the Chosen Foreign Language Course among Learners of Foreign Languages: A Case Study International Refereed Research Journal www.researchersworld.com 3(1), 87

[14] Stillwell, C., Curabba, B., Alexander, K., Kidd, A., Kim, E., Stone, P., \& Wyle, C. (2010).

[15] Students transcribing tasks: Noticing fluency, accuracy, and complexity. ELT Journal, 64(4),

[16] 445-455.

[17] Vygotsky, L.S. (1978). "Mind in Society" in M. Cole et al. [eds]. The Development of Higher

[18] Psychological Process. Cambridge, MA: Harvard University Press.

[19] Woodrow, L. (2006). Anxiety and speaking English as a second language. RELC Journal, 37(3),308-328. 